\title{
Phillygenin Alleviates Lipopolysaccharide-Induced Acute Pneumonia by Modulating the Tumor Necrosis Factor a Signaling Pathway
}

Cong-jie Wang

Yantai Yuhuangding Hospital

\section{Yu-jun Tan}

Lunan Pharmaceutical Group Co. Ltd.

Chang-jun Lv

Binzhou Medical University

Zhong Liu

Lunan Pharmaceutical Group Co. LTD.

\section{Gui-min Zhang}

Lunan Pharmaceutical Group Co. Ltd.

\section{Bing-bing Li}

Lunan Pharmaceutical Group Co. Ltd.

Guo-liang Cheng ( $\nabla$ september1984@aliyun.com )

Lunan Pharmaceutical Group Co. Ltd.

\section{Research Article}

Keywords: phillygenin, pregnane X receptor, acute pneumonia, inflammation, TNF-a

Posted Date: May 7th, 2021

DOl: https://doi.org/10.21203/rs.3.rs-450401/v1

License: (c) (1) This work is licensed under a Creative Commons Attribution 4.0 International License. Read Full License 


\section{Abstract}

Purpose: There is an urgent need to develop effective anti-pneumonia drugs. Phillygenin (PHI) is derived from Forsythia suspense and possesses anti-inflammation, anti-oxidant bioactivities. In the present study, we aimed to evaluate the therapeutic potential of phillygenin (PHI) on lipopolysaccharide (LPS)-induced acute pneumonia.

Methods: The molecular target of PHI was predicted by bioinformatic analysis. Hollow fiber-based ligand fishing (HFLF) strategy and luciferase reporter assay were further used to identify the target of PHI. LPSinduced acute pneumonia rat model and A549 cells model were used to evaluate PHI function. TNF-a pathway and apoptosis associated proteins were detected by Western Blot, immunofluorescence and immunohistochemistry. Cell cycle and cytokines were determined by flow cytometry.

Results: The bioinformatic analysis and luciferase reporter assay identified that the target protein of PHI was pregnane X receptor (PXR) PHI could directly bind to PXR protein and inhibit NF-kB P65 activity. PHI significantly decreased the expression of phosphorylated JNK, P38, Erk, P65 in acute pneumonia rat model. PHI also declined the expression of Bax, Caspase-3 and Caspase-9 and repressed lung epithelial cell apoptosis induced by LPS in vivo and in vitro. In addition, PHI inhibited inflammation cytokines production including TNF-a, IFN- $\gamma$, IL-6, IL-1 $\beta$ and IL-18.

Conclusions: $\mathrm{PHI}$ significantly alleviated LPS-induced lung injury in vivo by exerting anti-inflammatory effects. This is the first study to demonstrate that PHI, a small molecule natural product, significantly alleviates LPS-induced acute pneumonia by binding to PXR. Thus, PHI can be a novel therapeutic agent for pneumonia.

\section{Introduction}

Pneumonia, an acute lung parenchyma infection, is a major threat to public health. Globally, pneumonia affects more than 150 million individuals every year and results in approximately 2 million deaths (Prevention.). According to the World Health Organization (WHO), pneumonia is the leading cause of death among children. Approximately one million children aged less than 5 years die of pneumonia, which accounts for $16 \%$ of all pneumonia-related death cases[1]. The etiological agent for pneumonia is the microbial pathogens that produce endotoxin[2]. Additionally, pneumonia is associated with aberrant inflammatory stimulations[3]. Pneumonia caused due to persistent gram-negative bacterial infection is associated with high morbidity and mortality worldwide[4]. Lipopolysaccharide (LPS), the predominant component of gram-negative bacterial cell wall, is reported to be a potent endotoxin and a crucial factor that mediates inflammation[5].

In vivo, LPS could significantly induce TNFa production and result to exacerbation of inflammation, promote oxidative response, and involved in the pathogenesis of many diseases, including pneumonia[6]. While TNF-a generation enhances oxidative stress which subsequent activation of pro-inflammatory and pro-oxidative transcription factors nuclear factor kappa-B (NF-kB), the later involved in the activation of 
inflammatory cytokines like, IL-6, IL-1 $\beta$, etc[7, 8]. In another way, TNF-a mediated p38/MAPK, and caspase signal pathway activations, which subsequently modulate cell apoptosis[9, 10]. All these cytokines and transcription factors are involved in occurrence and development of pneumonia. Pregnane $\mathrm{X}$ receptor (PXR), as a ligand-dependent transcription factor, is a member of the nuclear receptors superfamily. PXR and retinoid $\mathrm{X}$ receptor alpha ( $\mathrm{RXRa}$ ) form heterodimers to regulate gene transcription, especially drugmetabolizing enzyme CYP3A4[11, 12]. Additionally, PXR exerts anti-inflammatory effect by suppressing the activity of NF-KB or the expression of NF-KB target genes[13]. However, in pneumonia, it is still unknown whether PXR can inhibit inflammation by regulating NF-KB after being activated.

Recently, a variety of herbal medicines have also been identified as ligands of PXR and could active PXR[14]. Astragalus injection and Astragalus granules could also significantly transactivated CYP3A4 reporter gene luciferase activity in PXR-transfected LS174T cells[15]. Sophora flavescens was shown to activate PXR in a concentration-dependent manner, which is widely used for treatmenting viral hepatitis, cancer, viral myocarditis, gastrointestinal hemorrhage, and skin diseases[16]. Therefore accumulative evidences have revealed the PXR-mediated herbal effect against multiple human diseases [17]. Phillygenin (PHI) is a small molecule natural product and a main active ingredient of Forsythia suspensa (Thunb.), which is used in many traditional Chinese medicine prescriptions, e.g Bi-Yuan-Tong-Qiao granule, Shuang-Huang-Lian oral liquid[18]. In the efficacy of these prescriptions drugs, PHI plays important roles due to possessing many pharmacological activities, such as anti-inflammation, antitumor, anti-oxidant and anti-hypertensive effects[18]. But the function mechanism of PHI is not fully elucidated, especially the anti-inflammatory mechanism still needs further study.

The bioinformatic analysis of Traditional Chinese Medicine (TCM) is widely used to explore the potential molecular mechanisms of drugs used in TCM, which has enabled increased acceptance of the biological efficacy of TCM drugs. In this study, it is found that PHI could bind to PXR by bioinformatic analysis. Additionally, the activated function of PHI on PXR was determined using luciferase reporter system. And the effects of PHI on LPS-induced acute pneumonia rat model and LPS-treated cell model were evaluated to explore the pharmacodynamic effects and potential mechanisms of $\mathrm{PHI}$ in acute pneumonia. $\mathrm{PHI}$ could ameliorate LPS-induced acute pneumonia in vivo and in vitro by binding to PXR and inhibiting NF$\mathrm{Kb}$.

\section{Materials And Methods}

\section{Binding screening of Phillygenin and PXR}

Target of phillygenin was predicted using the BATMAN-TCM online tool. It was showed that phillygenin could bind to PXR (Fig 2A). To further determine relationship between Phillygenin and PXR, binding screening assay was performed as previously described[19]. In brief, the hollow fiber-based ligand fishing (HFLF) strategy was used to determine the binding between phillygenin and PXR. Hollow fiber membranes with an inner diameter of $500 \mu \mathrm{m}$ and a pore size of $0.2 \mu \mathrm{m}$ were purchased from GE Healthcare. PXR protein was injected into the lumen of hollow fibers treated with acetone, methanol, and 
$\mathrm{ddH}_{2} \mathrm{O}$. Hollow fiber membranes filled with proteins were sealed by heating and placed into phillygenin extract $(10 \mathrm{mg} / \mathrm{ml})$, incubated in an ultrasonic bath at $37^{\circ} \mathrm{C}$ for $30 \mathrm{~min}$. After washing with phosphatebuffered saline (PBS), bound compounds formed in the lumen were dissociated with $30 \mu \mathrm{l}$ of methanol. The fluid was centrifuged at $10000 \times \mathrm{g}$ for $10 \mathrm{~min}$. Twenty microliters of supernatant was used for liquid chromatography-mass spectrometry (LC-MS) analysis. The flow chart is shown in Fig 2B.

\section{Transient transfection and luciferase assays}

A549 cells were used for luciferase assays. Recombinant pGL-3 plasmids containing CYP3A4 promoter and pcDNA3.1 plasmid containing PXR cDNA were transiently co-transfected into A549 cells. After $48 \mathrm{~h}$, different concentrations of PHI were used to treat the transfected A549 cells for $16 \mathrm{~h}$. Each treatment was repeated three times. The cells were lysed, and luciferase activity was quantified using the DualLuciferase Reporter Assay System (Promega, WI, USA) according to the manufacturer's instructions. Relative luciferase activities were shown by normalizing the firefly luciferase activity to Renilla luciferase activity. To evaluate whether PHI could inhibit NF-KB by PXR, NF-KB p65 activity was detected using NFKB (p65) transcription factor assay kit (Cayman Chemical, MI, USA). A549 cells were cultured in 24 well plate and then transfected with siRNA against PXR. 24 hours later, the cells were treated with or without $\mathrm{PHI}$ and LPS for 24 hours. According to the manufacture's instruction, $10 \mu \mathrm{l}$ of nuclear extracts were used for detection.

\section{LPS-induced acute pneumonia rat model}

Thirty-six male Sprague Dawley (SD) rats (Rattus norvegicus) aged 8-10 weeks with an average weight of 220-250 g were purchased from Vital River Laboratory (Vital River Laboratory Animal Technology, Beijing, China). The animals were housed at the Center for New Drug Safety Evaluation, Lunan Pharmaceutical (Lunan Pharmaceutical Group Co., Ltd., Linyi, China). The experimental protocols were approved by the Animal Ethics Committee of Lunan Pharmaceutical Group Co. Ltd. The animals were randomly divided into the following 3 groups ( $n=12)$ : control (vehicle treatment), LPS (LPS treatment), and PHI (LPS+PHI treatment) group. The LPS and PHI groups were intranasally administered with LPS ( $20 \mathrm{mg} / \mathrm{kg}$ bodyweight). Next, the animals were intragastrically administered with vehicle or $\mathrm{PHI}(1.3 \mathrm{mg} / \mathrm{kg}$ bodyweight; three times a day) continuously for 7 days. According to the drug instruction and the conversion of human body surface area into rat body surface area, the dosage of rat is $1.3 \mathrm{mg} / \mathrm{kg}$. At the end of experiment, the bronchoalveolar fluid (BALF), blood samples and lung tissue were collected from all animals.

\section{Staining}

The pathological changes in the lung tissue were evaluated by hematoxylin and eosin (H\&E) staining and terminal deoxynucleotidyl transferase dUTP nick end labeling (TUNEL) staining as described previously[20]. Briefly, the lung tissues of rats were fixed in $4 \%$ paraformaldehyde buffer overnight and embedded in paraffin. The paraffin-embedded tissue was cut into $2 \mu \mathrm{m}$ sections. The sections were subjected to H\&E and TUNEL staining. 
The expression levels of target proteins predicted by bioinformatic and network pharmacology analyses were validated by immunohistochemical $(\mathrm{IHC})$ staining. The expression levels of tumor necrosis factor (TNF)-a signaling pathway-related proteins were evaluated (Supplementary Materials and Methods).

\section{Immunofluorescence and western blotting}

To investigate the expression levels of TNF-a signaling pathway-related protein, such as phosphorylated JNK, P38, ERK, P65, Bax, Bcl-2, caspase-3, and caspase-9, different treatment groups of A549 cells were subjected to immunofluorescence and western blotting analyses (Supplementary Materials and Methods).

\section{Flow cytometry and ELISA}

The BALF and serum samples were obtained from all experimental animals. The levels of inflammatory factors in the BALF and serum samples were detected by flow cytometry and ELISA.

To determine the levels of cytokines, the rat BALF sample was filtered to obtain single-cell suspensions and washed with $10 \mathrm{~mL}$ of Roswell Park Memorial Institute (RPMI)-1640 medium supplemented with 10\%

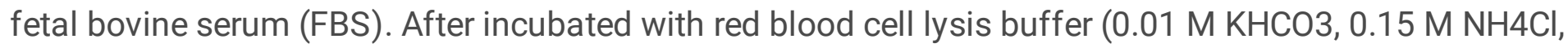
and 0.1 M EDTA-Na2, pH 7.4), the cells were resuspended in RPMI-1640 medium and counted. Next, the cells $(5 \times 106$ cells/well) were cultured in 6-well plates and incubated with phorbol 12-myristate 13-acetate (PMA; $50 \mathrm{ng} / \mathrm{mL})$, ionomycin $(100 \mathrm{ng} / \mathrm{mL})$, and Brefeldin A (BFA; $10 \mu \mathrm{g} / \mathrm{mL})$ for $6 \mathrm{~h}$ at $37^{\circ} \mathrm{C}$. The cells were harvested and detected using flow cytometry (Supplementary Materials and Methods)..

The respective ELISA kits were used to detect serum levels of TNF-a, IFN- $\gamma$, IL-1 $1 \beta$, IL-6, and IL-18 in rats following the manufacturer's instructions (Supplementary Materials and Methods).

\section{Cell culture and cell inhibition, viability assays}

The human lung adenocarcinoma epithelial-like cell line A549 (\#TCHu150) was obtained from China Center For Type Culture Collection (CCTCC, Wuhan University, Wuhan, Hubei province, China) and cultured as previously described[21].

Cell proliferation was analyzed by using the CellTiter $96 \AA$ Aqueous Non-radioactive Cell proliferation Kits (\#TB169, Promega Corporation, Madison, WI, USA.), following the manufacturer's instructions. The halfmaximal effective concentration (EC50) of PHI was calculated in the Graphpad Prism 5.0 software.

The effect of PHI on LPS-induced apoptosis of A549 cells was determined by flow cytometry using the Annexin V-FITC/propidium iodide (PI) apoptosis detection kit (BD Biosciences, San Jose, CA).

\section{Statistical analysis}

The data were expressed as mean \pm standard deviation (Mean \pm S.D.). Statistical analyses of all data were performed with SPSS 18.0 (IBM Corporation, USA). If the data passed the tests for normality and 
homogeneity of variance, the one-way ANOVA was selected for statistical analysis, otherwise, a nonparametric test was applied. The difference was considered statistically significant when the P-value was less than 0.05 .

\section{Results}

\section{PHI could bind with PXR}

To investigate the potential bioactivities of $\mathrm{PHI}$, the target proteins of $\mathrm{PHI}$ were predicted using the BATMAN-TCM online tool (http://bionet.ncpsb.org.cn/batman-tcm/). As shown in Fig. 1a, pregnane $X$ receptor is a pentical target protein of PHI. To further confirm this, the hollow fiber-based ligand fishing (HFLF) strategy was used to verify whether PXR could bind with PHI. The hollow fibers filled with PXR protein in order to obtain the ligand molecules. Then LC-MS was used to identify the ligand dissociated from target-ligand complexes. The screening procedure was showed in Figure 2B left. The structure of $\mathrm{PHI}$ was showed in Fig. 1b. Concentration of PHI was detected at different washing times ranging from 5 to $45 \mathrm{~min}$ after incubation, and the concentration peaked at $15 \mathrm{~min}$, and reached a plateau at $30 \mathrm{~min}$ (Fig. 1b). The results indicated that PHI could bind with PXR.

\section{PHI efficiently inhibit NF-kB activity in vitro}

Cytochrome P450-3A4 (CYP3A4) is highly sensitive to upstream modulation by PXR, so here we used a dual-luciferase reporter containing pGL3-CYP3A4 promoter and pcDNA3.1-PXR to identify the bioactivity of PHI. The result showed that PXR protein could promote the luciferase activity by binding to the promoter of CYP3A4. In the presence of PHI, PXR further increased the luciferase activity in a dosedependent manner (Fig. 1C). Then we detected the effect of PHI on NF-KB activity in the presence or in the absence of PXR. It was showed that PHI inhibited NF-KB p65 activity in the presence of PXR protein in a dose-dependent manner significantly, however, the inhibited function of PHI was abolished when PXR was down regulate by specific siRNA (Fig. 1d). These results suggested that PHI could exert an inhibited function on NF-KB by targeting PXR protein.

\section{PHI ameliorated LPS-induced acute pneumonia in vivo}

Although the bioinformatics analysis of microarray dataset (GSE110147) demonstrated that TNF-a signaling pathway was potential target of pneumonia. And it was confirmed that $\mathrm{PHI}$ could efficiently inhibit NFKB P65 promoter activity in the present of PXR. However, the actual effect of PHI in pneumonia is still unknown. In the subsequent research, the effect of PHI on LPS-induced pneumonia was evaluated using SD rats. The results of H\&E and TUNEL staining of rat lung tissues demonstrated that PHI significantly alleviated LPS-induced tissue injury (Fig. 2a). Additionally, the expression levels of TNF-a signal pathway-related proteins were detected by western blotting and IHC staining. The protein expression levels of JNK, P38, ERK1/2, and NF-KB p65 in the LPS and PHI groups were similar to those in the control group. However, the protein expression levels of phosphorylated JNK, P38, ERK1/2, and NF-KB p65 in the PHI group were significantly downregulated when compared to those in the LPS group. The 
expression level of Bax, cleaved caspase-3, and caspase-9 exhibited a similar pattern (Fig. 2b). The results of western blotting analysis concurred with those of IHC assays (Fig. 2c). This suggested that the TNF-a signaling pathway-related proteins are involved in LPS-induced acute pneumonia and that PHI alleviated LPS-induced pneumonia by modulating the expression of these proteins.

\section{PHI alleviated LPS-induced acute inflammation in vivo}

Acute inflammation is reported to be the main cause of pneumonia. The anti-inflammatory effect of PHI was evaluated by measuring the levels of inflammatory factors in the BALF and serum of rats by flow cytometry and ELISA. The expression levels of TNF-a (Fig. 3a), IFN-y (Fig. 3b), and IL-18 (Fig. 3c) in the BALF of LPS group were significantly higher than those in the BALF of control group. Treatment with PHI mitigated the LPS-induced enhanced expression level of these cytokines. The levels of these inflammatory factors in the serum exhibited a similar pattern as those in the BALF. Compared to the control group, the LPS group exhibited upregulated expression levels of IL-1 $\beta$ and IL-6. However, treatment with PHI mitigated the LPS-induced enhanced expression levels of IL-1 $\beta$ and IL-6 (Fig. 3d, e). These results indicate that PHI can alleviate LPS-induced acute pneumonia by suppressing inflammation.

\section{PHI mitigated LPS-induced cell apoptosis in vitro by modulating the TNF-a signaling pathway}

The results of in vivo experiments suggested that $\mathrm{PHI}$ is involved in mitigating LPS-induced dysregulation of TNF-a pathway. However, the direct effects of PHI are still not well understood. The A549 cells were pre-incubated with LPS $(1 \mu \mathrm{g} / \mathrm{mL})$ for $2 \mathrm{~h}$ and treated with various concentrations of PHI (10-3 to 106 $\mu \mathrm{g} / \mathrm{mL}$ ) for $24 \mathrm{~h}$. Treatment with PHI dose-dependently mitigated the LPS-induced decreased cell proliferation (EC50 value $=14.66 \mu \mathrm{g} / \mathrm{ml}$ ) (Fig. 4a). Subsequently, the effect of various durations $(0,6,12$, and $24 \mathrm{~h}$ ) of treatment with $20 \mathrm{mM} \mathrm{PHI}$ on the viability of A549 cells pre-stimulated with LPS $(1 \mu \mathrm{g} / \mathrm{mL})$ for $2 \mathrm{~h}$ was evaluated. Treatment with PHI mitigated LPS-induced decreased cell viability in a treatment duration-dependent pattern (Fig. 4b). LPS significantly promoted A549 cell apoptosis (early apoptosis rates of control and LPS groups were 3.31 and $37.03 \%$, respectively), which was mitigated by PHI treatment (10.59\% early apoptosis rate) (Fig. 4c). Moreover, the proportion of LPS-treated cells in the G0/G1 phase was higher than that of control and PHI-treated cells. The proportion of cells in the S phase was similar among the three groups. However, the proportion of LPS-treated cells in the G2/M phase was lower than that of control cells (31.85\% in control cells vs $4.88 \%$ in LPS-treated cells). The proportion of PHI-treated cells (21.23\%) in the G2/M phase was higher than that of LPS-treated cells (4.88\%) (Fig. $4 \mathrm{~d}$ ). The effect of PHI treatment on the LPS-induced enhanced production of inflammatory proteins in the A549 cells was evaluated by immunofluorescence staining and western blotting. The expression levels of phosphorylated JNK, P38, ERK, P65, Bax, caspase 3, and caspase 9 in the LPS-treated cells were upregulated when compared to those in the control cells. Treatment with PHI significantly mitigated the LPS-induced upregulated expression of these proteins. In contrast, the Bcl-2 protein levels were dramatically inhibited after LPS-treatment but almost recovered to normal by PHI treatment (Fig. 5a). The results of western blotting assay concurred with those of immunofluorescence staining (Fig. 5b). These 
findings indicate that PHI directly inhibits A549 cell apoptosis induced by LPS through modulating the expression of TNF-a signaling pathway-related protein.

\section{Discussion}

Various pro-inflammatory factors, such as TNF-a, IL-1, and IL- 6 are involved in modulating inflammation that initiates and drives acute pneumonia[22, 23]. In this study, the R-limma package was used to analyze the expression profile of pneumonia-related genes via systematic statistical analysis. In total, 3,899 differentially expressed genes (including 1,066 upregulated and 2,833 downregulated) were identified between the pneumonia and non-pneumonia groups. Based on the screening criteria, 227 genes involved in various signaling pathways were identified. Of these, 28 differentially expressed genes were associated with the TNF-a signaling pathway (Supplemental Fig. S1). TNF-a is reported to be involved in the pathogenesis of pneumonia as it has various functions, such as promoting leukocyte accumulation, cell proliferation at the injury site and inducing oxidative stress, cell apoptosis, necrosis, angiogenesis, and tissue remodeling[24-26].

In airway epithelial cells, NF-kB activation plays pivotal roles during the early induction of inflammatory responses to bacteria, including generation of pro-inflammatory cytokines and anti-microbial peptide production[27, 28]. TNF-a signaling pathway and NF-KB pathway have close biological relationship. The two can regulate each other efficiently[29]. Several inflammatory mediators, such as bacterium-derived LPS may stimulate TNF-a production[30]. TNF-a then activates multiple pathways and promotes the expression of various proteins, including NF-KB, ERK, JNK, P38, Bax, and Caspase-3/9, which contribute to the pathogenesis of pneumonia[31-33]. MAPK and NF-KB signaling pathways play an important role in many physiological functions of TNF-a mediated pneumonia. In one way, mediate inflammatory response. In epithelial cells, the receptor binding TNFa subsequently activated NF-kB, the later translocate into nucleus, binds to and activates inflammatory cytokines promoter, such as IL-6 and IL-1 $\beta$ [34]. In most cases, for these cytokines production, only NF-KB regulation is not sufficient which requires activated JNK, ERK, and the p38 MAPK pathways[35]. In respiratory epithelial cells, the JNK and ERK arms of the MAPK pathway, along with NF-KB, activate inflammatory cytokine transcriptions. Accumulated inflammatory cytokines subsequently resulted to cell apoptosis, the other way of MAPK and NF-KB mediated pathology of pneumonia[36]. As we known, the most common way of cell death is apoptosis, which is an active death or cell suicide to response inflammatory stimulation[37]. However, the relationship between apoptosis and pneumonia is complicated due to there are two types of AECs (alveolar epithelial cells), which type I facilitate to apoptosis onset inflammatory injury occurred, and in case, triggered type II proliferation or promoting the remaining type I cells to differentiate into AECs I during the tissue repair process[38]. However, repetitive cycles of "injury-repair" finally consequence of recruited fibroblast accumulating in the injured tissue and developing fibrosis[39]. In pneumonia, previous studies demonstrated that TNF-a promotes epithelial cells apoptosis of injured lung tissue by activating caspases and promoting the release of reactive oxygen species (ROS), cytochrome c, and Bax[40, 41]. The Caspases (caspase-3 and/or caspase-9) mediated the process of epithelial cells apoptosis is 
regulated by MAPK and NF-KB[36]. PHI, as an anti-inflammation natural small molecule product, could bind to PXR protein and further inhibit NF-KB P65 activity (Fig. 1).

In this study, PHI was administered to LPS-treated SD rats and A549 cells. Treatment with PHI significantly alleviated LPS-induced lung injury and upregulated the expression levels of TNF-a signaling pathway-related proteins, such as phosphorylated JNK, P38, ERK1/2, NF-KBp65, Bax, caspase-3, and caspase-9 (Fig. 2). TNF-a-induced inflammatory factors, such as IFN- - , IL-18, IL-1 3 , and IL-6 are reported to play a critical role in the pathogenesis of pneumonia[22, 42]. Levels of inflammatory factors in the BALF and serum of rats were detected by flow cytometry and ELISA. Treatment with PHI alleviated LPSinduced acute pneumonia by suppressing inflammation (Fig. 3). In vivo, PHI effectively mitigated LPSinduced cell apoptosis and increased A549 cell proliferation (Fig. 4) by regulating the expression of TNF-a signaling pathway-related proteins, such as p-JNK, p-P38, p-ERK, p-p65, Bax, caspase-3, and caspase-9 (Fig. 5).

$\mathrm{PHI}$ is a lignan component extracted from Forsythiae Fructus. Pharmacological studies have shown that PHI has the effects of anti-inflammatory[43, 44], liver protection[45], anti-oxidant and anti-tumor[46, 47]. $\mathrm{PHI}$ was contained in many prescription of Traditional Chinese Medicine, such as Bi-Yuan-Tong-Qiao granule (BYTQG) that is a mixture of 14 medical herbs, has a long history of usage for treating upper respiratory tract infection. However, the application of TCM medicinal formulations, such as BYTQG is limited in the western world. This is mainly because TCM is based on a complicated theory of yin-yang and five elements, which is in contrast to the precise treatment theories of modern medicine[48]. To improve the global acceptance of TCM, bioinformatics tools have been developed to analyze the TCM medicinal herbs. In the research, PHI was found to be a primary component in BYTQG by UPLC/MS analysis and be associated with the TNF-a signaling pathway (supplemental Fig. S2), which is a potential mechanism for treating sinusitis and a new clinical application for pneumonia.

In summary, we demonstrated that pregnane $\mathrm{X}$ receptor is a target of phillygenin and the latter can effectively inhibit the activity of NF-KB. Especially in A549 cell model and animal model, PHI displays a protective role in pneumonia. $\mathrm{PHI}$ inhibited inflammation cytokines production and repressed lung epithelial cells apoptosis. To the best of our knowledge, this is the first study to evaluate the inhibitory effect of PHI on TNF-a signaling pathway and demonstrate that PHI alleviates LPS-induced acute pneumonia. Thus, $\mathrm{PHI}$ can be a potential novel therapeutic agent.

\section{Abbreviations}

PHI, Phillygenin; PXR, pregnane X receptor; LPS, Lipopolysaccharide; HFLF, Hollow fiber-based ligand fishing; TCM, Traditional Chinese Medicine; GEO, Gene Expression Omnibus; NF-KB, nuclear factor kappa$\mathrm{B}$; UPLC/MS, ultraperformance liquid chromatography-mass spectrometry; PI, propidium iodide; $\mathrm{H} \& \mathrm{E}$, hematoxylin and eosin

\section{Declarations}




\section{Author's Contributions}

Conceptualization, Guo-liang Cheng; methodology, Cong-jie Wang, Bing-bing Li; software, Guo-liang Cheng; data curation, Zhong Liu and Gui-min Zhang; pathological detection, Yu-jun Tan; writing-original draft preparation, Cong-jie Wang; writing-review and editing, Chang-jun Lv. All authors read and approved the final manuscript.

\section{Compliance with ethical standards}

Funding information: Not applicable.

Conflict of interest: No potential conflict of interest is reported by the authors.

Ethical approval: All animal experiments were approved by the Animal Ethics Committee of Lunan Pharmaceutical Group Co. Ltd.

Consent to participate: Not applicable.

Consent for publication: Not applicable.

Code availability: Not applicable.

\section{References}

1. Organization WH: Pneumonia. (2019). Accessed.

2. Prina E, Ranzani OT, Polverino E, Cillóniz C, Ferrer M, Fernandez L, Puig de la Bellacasa J, Menéndez R, Mensa J, Torres A (2015) Risk factors associated with potentially antibiotic-resistant pathogens in community-acquired pneumonia. Ann Am Thorac Soc 12(2):153-60. doi: 10.1513/AnnalsATS.201407-3050C.

3. Cilloniz C, Ewig S, Gabarrus A, Ferrer M, Puig de la Bella Casa J, Mensa J, Torres A (2017) Seasonality of pathogens causing community-acquired pneumonia. Respirology 22(4):778-85. doi: 10.1111/resp.12978.

4. Vladimer GI, Weng D, Paquette SW, Vanaja SK, Rathinam VA, Aune MH, Conlon JE, Burbage JJ, Proulx MK, Liu Q, Reed G, Mecsas JC, Iwakura Y, Bertin J, Goguen JD, Fitzgerald KA, Lien E (2012) The NLRP12 inflammasome recognizes Yersinia pestis. Immunity 37(1):96-107. doi: 10.1016/j.immuni.2012.07.006.

5. Lord R, Jones AM, Horsley A (2020) Antibiotic treatment for Burkholderia cepacia complex in people with cystic fibrosis experiencing a pulmonary exacerbation. Cochrane Database Syst Rev. 4(4):CD009529. doi: 10.1002/14651858.CD009529.pub4.

6. Mukhopadhyay S, Hoidal JR, Mukherjee TK (2006) Role of TNFalpha in pulmonary pathophysiology. Respir Res 7(1):125. doi: 10.1186/1465-9921-7-125. 
7. Jeong DG, Seo JH, Heo SH, Choi YK, Jeong ES (2015) Tumor necrosis factor-alpha deficiency impairs host defense against Streptococcus pneumoniae. Lab Anim Res 31(2):78-85. doi: 10.5625/lar.2015.31.2.78.

8. Zhang L, Dong L, Tang Y, Li M, Zhang M (2020) MiR-146b protects against the inflammation injury in pediatric pneumonia through MyD88/NF-kappaB signaling pathway. Infect Dis (Lond). 52(1):23-32. doi: 10.1080/23744235.2019.1671987.

9. Borges VM, Vandivier RW, McPhillips KA, Kench JA, Morimoto K, Groshong SD, Richens TR, Graham BB, Muldrow AM, Van Heule L, Henson PM, Janssen WJ (2009) TNFalpha inhibits apoptotic cell clearance in the lung, exacerbating acute inflammation. Am J Physiol Lung Cell Mol Physiol 297(4):L586-95. doi: 10.1152/ajplung.90569.2008.

10. Cornell TT, Hinkovska-Galcheva V, Sun L, Cai Q, Hershenson MB, Vanway S, Shanley TP (2009) Ceramide-dependent PP2A regulation of TNFalpha-induced IL-8 production in respiratory epithelial cells. Am J Physiol Lung Cell Mol Physiol 296(5):L849-56. doi: 10.1152/ajplung.90516.2008.

11. Mani S, Dou W, Redinbo MR (2013) PXR antagonists and implication in drug metabolism. Drug Metab Rev 45(1):60-72. doi: 10.3109/03602532.2012.746363.

12. Willson TM, Kliewer SA (2002) PXR, CAR and drug metabolism. Nat Rev Drug Discov 1(4):259-66. doi: $10.1038 / \mathrm{nrd} 753$.

13. Zhou C, Tabb MM, Nelson EL, Grün F, Verma S, Sadatrafiei A, Lin M, Mallick S, Forman BM, Thummel KE, Blumberg B (2006) Mutual repression between steroid and xenobiotic receptor and NF-kappaB signaling pathways links xenobiotic metabolism and inflammation. J Clin Invest 116(8):2280-9. doi: $10.1172 / \mathrm{JCl} 26283$.

14. Yu C, Chai X, Yu L, Chen S, Zeng S (2011) Identification of novel pregnane X receptor activators from traditional Chinese medicines. J Ethnopharmacol 136(1):137-43. doi: 10.1016/j.jep.2011.04.022.

15. Zhang Y, Huang L, Bi H, Cui Y, Li J, Wang X, Qin X, Chen J, Huang M (2013) Study of the upregulation of the activity of cytochrome P450 3A isoforms by Astragalus injection and Astragalus granules in rats and in cells. Eur J Drug Metab Pharmacokinet 38(2):105-13. doi: 10.1007/s13318-012-0102-0.

16. Wang L, Li F, Lu J, Li G, Li D, Zhong XB, Guo GL, Ma X (2010) The Chinese herbal medicine Sophora flavescens activates pregnane $X$ receptor. Drug Metab Dispos 38(12):2226-31. doi: 10.1124/dmd.110.035253.

17. Xu C, Huang M, Bi H (2016) PXR- and CAR-mediated herbal effect on human diseases. Biochim Biophys Acta 1859(9):1121-9. doi: 10.1016/j.bbagrm.2016.02.009.

18. Wang L, Yan W, Tian Y, Xue H, Tang J, Zhang L (2020) Self-Microemulsifying Drug Delivery System of Phillygenin: Formulation Development, Characterization and Pharmacokinetic Evaluation. Pharmaceutics 12(2): 130. doi: 10.3390/pharmaceutics12020130.

19. Sun Y, Tan YJ, Lu ZZ, Li BB, Sun CH, Li T, Zhao LL, Liu Z, Zhang GM, Yao JC, Li J (2018) Arctigenin Inhibits Liver Cancer Tumorigenesis by Inhibiting Gankyrin Expression via C/EBPalpha and PPARalpha. Front Pharmacol 9:268. doi: 10.3389/fphar.2018.00268. 
20. Ren YS, Li HH, Yao JC, Tan YJ, Pan LH, Peng T, Zhao LL, Zhang GM, Yue J, Hu XM, Liu Z, Li J (2020) Application quantitative proteomics approach to identify differentially expressed proteins associated with cardiac protection mediated by cycloastragenol in acute myocardial infarction rats. J Proteomics 222:103691. doi: 10.1016/j.jprot.2020.103691.

21. Wang CJ, Li BB, Tan YJ, Zhang GM, Cheng GL, Ren YS (2020) MicroRNA-31/184 is involved in transforming growth factor-beta-induced apoptosis in A549 human alveolar adenocarcinoma cells. Life Sci 242:117205. doi: 10.1016/j.Ifs.2019.117205.

22. de Brito RC, Lucena-Silva N, Torres LC, Luna CF, Correia JB, da Silva GA (2016) The balance between the serum levels of IL- 6 and IL-10 cytokines discriminates mild and severe acute pneumonia. BMC Pulm Med 16(1):170. doi: 10.1186/s12890-016-0324-z.

23. Siebert JN, Hamann L, Verolet CM, Gameiro C, Grillet S, Siegrist CA, Posfay-Barbe KM (2018) TollInterleukin 1 Receptor Domain-Containing Adaptor Protein 180L Single-Nucleotide Polymorphism Is Associated With Susceptibility to Recurrent Pneumococcal Lower Respiratory Tract Infections in Children. Front Immunol 9:1780. doi: 10.3389/fimmu.2018.01780.

24. Malaviya R, Laskin JD, Laskin DL (2017) Anti-TNFalpha therapy in inflammatory lung diseases. Pharmacol Ther. 180:90-8. doi: 10.1016/j.pharmthera.2017.06.008.

25. Song C, Li H, Zhang Y, Yu J (2017) Effects of Pseudomonas aeruginosa and Streptococcus mitis mixed infection on TLR4-mediated immune response in acute pneumonia mouse model. BMC Microbiol 17(1):82. doi: 10.1186/s12866-017-0999-1.

26. Bacci MR, Leme RC, Zing NP, Murad N, Adami F, Hinnig PF, Feder D, Chagas AC, Fonseca FL (2015) IL6 and TNF-alpha serum levels are associated with early death in community-acquired pneumonia patients. Braz J Med Biol Res 48(5):427-32. doi: 10.1590/1414-431X20144402.

27. Trinchieri G, Sher A (2007) Cooperation of Toll-like receptor signals in innate immune defence. Nat Rev Immunol 7(3):179-90. doi: 10.1038/nri2038.

28. Sham HP, Walker KH, Abdulnour RE, Krishnamoorthy N, Douda DN, Norris PC, Barkas I, BenitoFigueroa S, Colby JK, Serhan CN, Levy BD (2018) 15-epi-Lipoxin A4, Resolvin D2, and Resolvin D3 Induce NF-kappaB Regulators in Bacterial Pneumonia. J Immunol. 200(8):2757-66. doi: 10.4049/jimmunol.1602090.

29. Hayden MS, Ghosh S (2014) Regulation of NF-kappaB by TNF family cytokines. Semin Immunol 26(3):253-66. doi: 10.1016/j.smim.2014.05.004.

30. Liu H, Kai L, Du H, Wang X, Wang Y (2019) LPS Inhibits Fatty Acid Absorption in Enterocytes through TNF-alpha Secreted by Macrophages. Cells. 8(12). doi: 10.3390/cells8121626.

31. Czikora I, Alli AA, Sridhar S, Matthay MA, Pillich H, Hudel M, Berisha B, Gorshkov B, Romero MJ, Gonzales J, Wu G, Huo Y, Su Y, Verin AD, Fulton D, Chakraborty T, Eaton DC, Lucas R (2017) Epithelial Sodium Channel-alpha Mediates the Protective Effect of the TNF-Derived TIP Peptide in Pneumolysin-Induced Endothelial Barrier Dysfunction. Front Immunol 8:842. doi: 10.3389/fimmu.2017.00842. 
32. Wen SH, Lin LN, Wu HJ, Yu L, Lin L, Zhu LL, Li HY, Zhang HL, Li CC (2018) TNF-alpha increases Staphylococcus aureus-induced death of human alveolar epithelial cell line A549 associated with RIP3-mediated necroptosis. Life Sci 195:81-6. doi: 10.1016/j.Ifs.2018.01.008.

33. Lee HC, Liu FC, Tsai CN, Chou AH, Liao CC, Yu HP (2020) Esculetin Ameliorates LipopolysaccharideInduced Acute Lung Injury in Mice Via Modulation of the AKT/ERK/NF-kappaB and RORgammat/IL17 Pathways. Inflammation 43(3):962-74. doi: 10.1007/s10753-020-01182-4.

34. Jiang $\mathrm{H}$, He H, Chen Y, Huang W, Cheng J, Ye J, Wang A, Tao J, Wang C, Liu Q, Jin T, Jiang W, Deng X, Zhou R (2017) Identification of a selective and direct NLRP3 inhibitor to treat inflammatory disorders. J Exp Med 214(11):3219-38. doi: 10.1084/jem.20171419.

35. Li J, Kartha S, lasvovskaia S, Tan A, Bhat RK, Manaligod JM, Page K, Brasier AR, Hershenson MB (2002) Regulation of human airway epithelial cell IL-8 expression by MAP kinases. Am J Physiol Lung Cell Mol Physiol 283(4):L690-9. doi: 10.1152/ajplung.00060.2002.

36. Liu T, Wu L, Wang D, Wang H, Chen J, Yang C, Bao J, Wu C (2016) Role of reactive oxygen speciesmediated MAPK and NF-kappaB activation in polygonatum cyrtonema lectin-induced apoptosis and autophagy in human lung adenocarcinoma A549 cells. J Biochem 160(6):315-24. doi:

$10.1093 / \mathrm{jb} / \mathrm{mvw} 040$.

37. Green DR (2020) Ghostly metabolic messages from dying cells. Nature 580(7801):36-7. doi: 10.1038/d41586-020-00641-0.

38. McClelland AD, Herman-Edelstein M, Komers R, Jha JC, Winbanks CE, Hagiwara S, Gregorevic P, Kantharidis P, Cooper ME. (2015) miR-21 promotes renal fibrosis in diabetic nephropathy by targeting PTEN and SMAD7. Clin Sci (Lond). 129(12):1237-49. doi: 10.1042/CS20150427.

39. Cloonan SM, Choi AM (2016) Mitochondria in lung disease. J Clin Invest. 126(3):809-20. doi: 10.1172/JCl81113.

40. Aggarwal BB, Gupta SC, Kim JH (2012) Historical perspectives on tumor necrosis factor and its superfamily: 25 years later, a golden journey. Blood 119(3):651-65. doi: 10.1182/blood-2011-04325225.

41. Catal F, Mete E, Tayman C, Topal E, Albayrak A, Sert H (2015) A human monoclonal anti-TNF alpha antibody (adalimumab) reduces airway inflammation and ameliorates lung histology in a murine model of acute asthma. Allergol Immunopathol (Madr) 43(1):14-8. doi: 10.1016/j.aller.2013.11.002.

42. Emura I, Usuda H (2016) Acute exacerbation of IPF has systemic consequences with multiple organ injury, with SRA(+) and TNF-alpha(+) cells in the systemic circulation playing central roles in multiple organ injury. BMC Pulm Med 16(1):138. doi: 10.1186/s12890-016-0298-x.

43. Lim H, Lee JG, Lee SH, Kim YS, Kim HP (2008) Anti-inflammatory activity of phylligenin, a lignan from the fruits of Forsythia koreana, and its cellular mechanism of action. $J$ Ethnopharmacol 118(1):113-7. doi: 10.1016/j.jep.2008.03.016.

44. Du B, Zhang L, Sun Y, Zhang G, Yao J, Jiang M, Pan L, Sun C (2019) Phillygenin exhibits antiinflammatory activity through modulating multiple cellular behaviors of mouse lymphocytes. Immunopharmacol Immunotoxicol 41(1):76-85. doi: 10.1080/08923973.2018.1547742. 
45. Song W, Wu J, Yu L, Peng Z (2018) Evaluation of the Pharmacokinetics and Hepatoprotective Effects of Phillygenin in Mouse. Biomed Res Int 2018:7964318. doi: 10.1155/2018/7964318.

46. Chang MJ, Hung TM, Min BS, Kim JC, Woo MH, Choi JS, Lee HK, Bae K (2008) Lignans from the Fruits of Forsythia suspensa (Thunb.) Vahl Protect High-Density Lipoprotein during Oxidative Stress. Biosci Biotechnol Biochem. 72(10):2750-5. doi: 10.1271/bbb.80392.

47. He J, Wei W, Yang Q, Wang Y (2019) Phillygenin Exerts In Vitro and In Vivo Antitumor Effects in DrugResistant Human Esophageal Cancer Cells by Inducing Mitochondrial-Mediated Apoptosis, ROS Generation, and Inhibition of the Nuclear Factor kappa B NF-kappaB Signalling Pathway. Med Sci Monit 25:739-45. doi: 10.12659/MSM.913138.

48. Huang $Y$, Yao P, Leung KW, Wang H, Kong XP, Wang L, Dong TTX, Chen Y, Tsim KWK (2018) The YinYang Property of Chinese Medicinal Herbs Relates to Chemical Composition but Not Anti-Oxidative Activity: An Illustration Using Spleen-Meridian Herbs. Front Pharmacol 9:1304. doi: 10.3389/fphar.2018.01304.

\section{Figures}




\section{Figure 1}

a

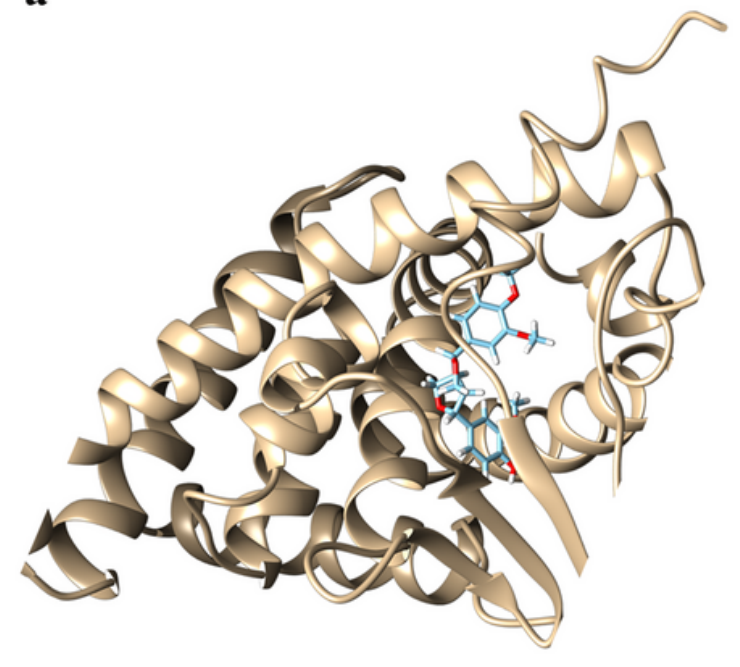

b

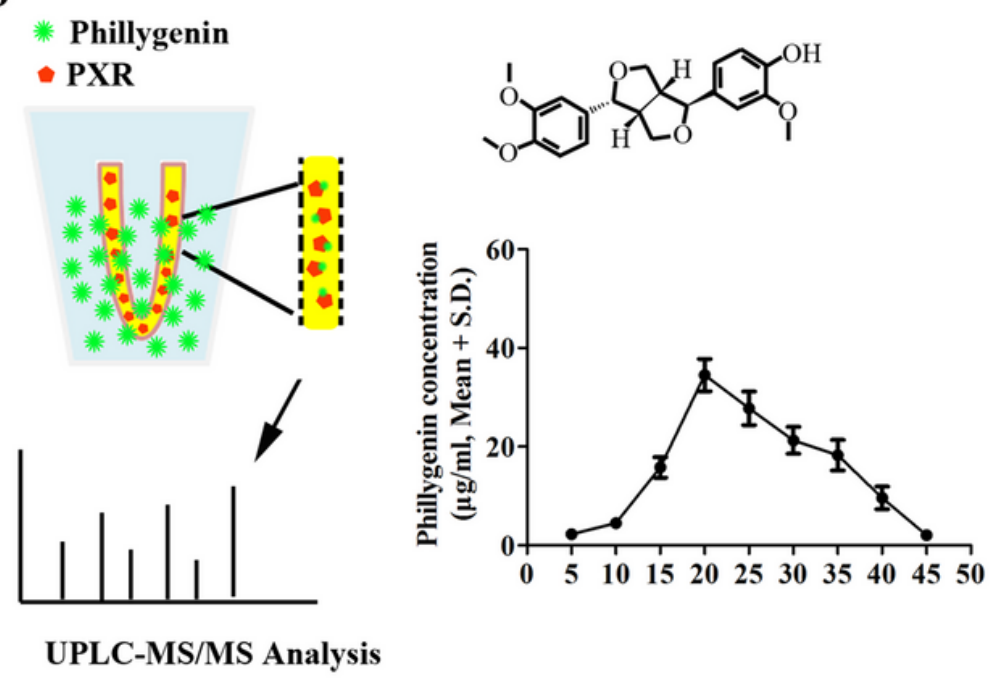

c

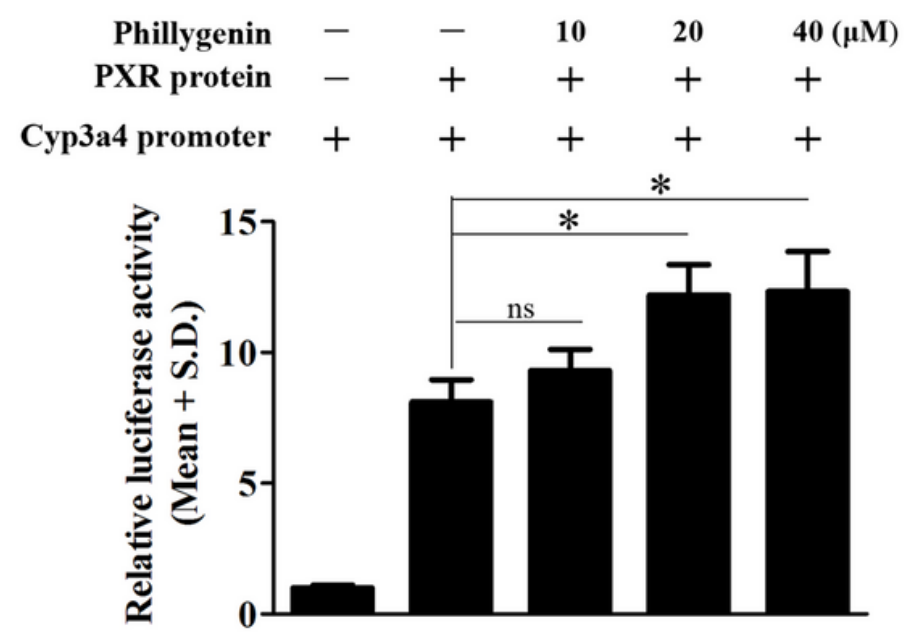

d
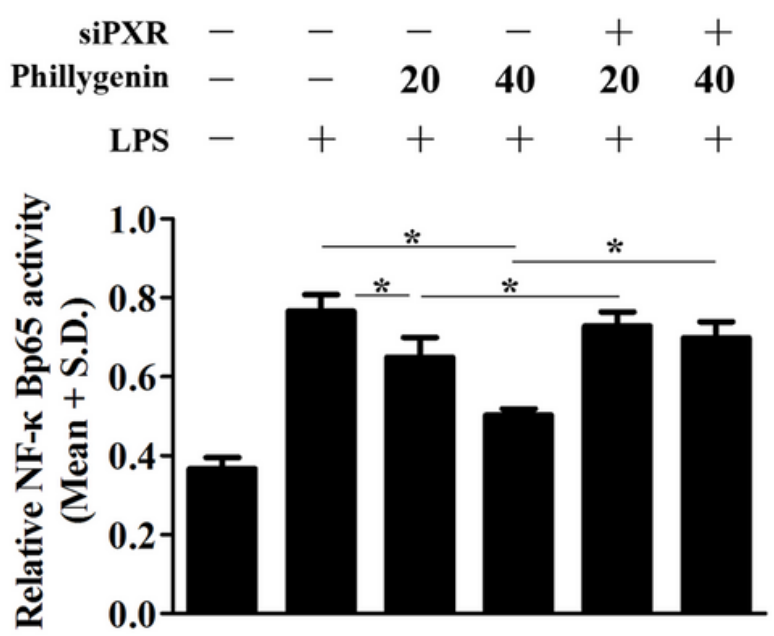

Figure 1

$\mathrm{PHI}$ could bind with PXR protein. (a) Predicted target of $\mathrm{PHI}$ is pregnane $\mathrm{X}$ receptor (PXR) using the BATMAN-TCM online tool. (b) Schematic illustration of HFLF combined with LC-MS methodology (left). The structure of $\mathrm{PHI}$ and the $\mathrm{PHI}$ concentration vs. washing time profiles of PHI in HFLF assay (right). (c) $\mathrm{PHI}$ increased the binding of PXR to CYP3A4 promoter in vitro. (d) PHI inhibited NFkB p65 activity in the presence of PXR protein in a dose-dependent manner. 
Figure 2

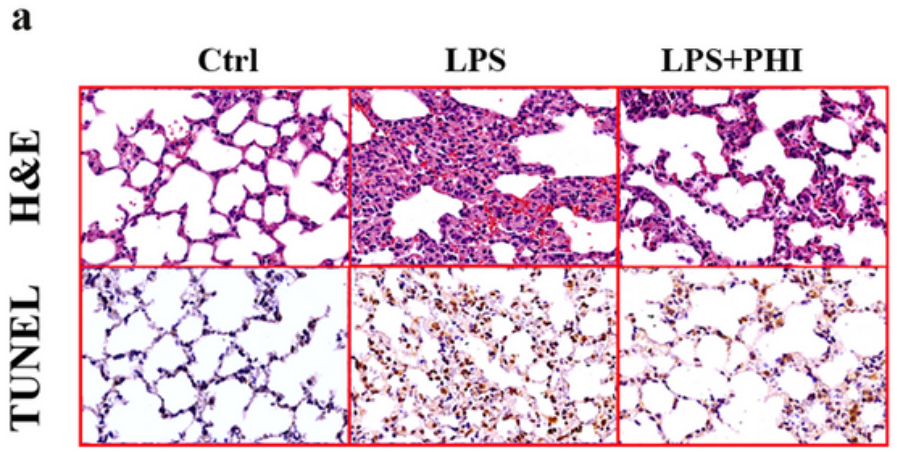

b
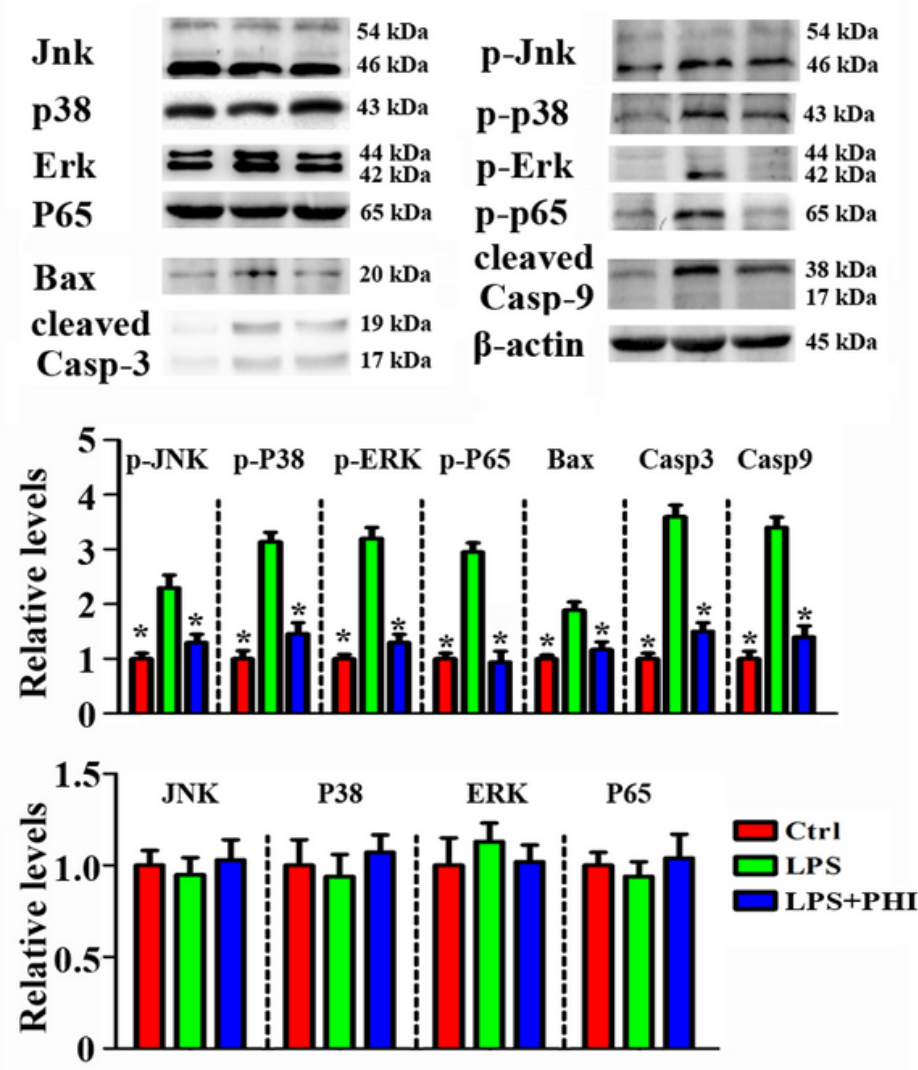

c

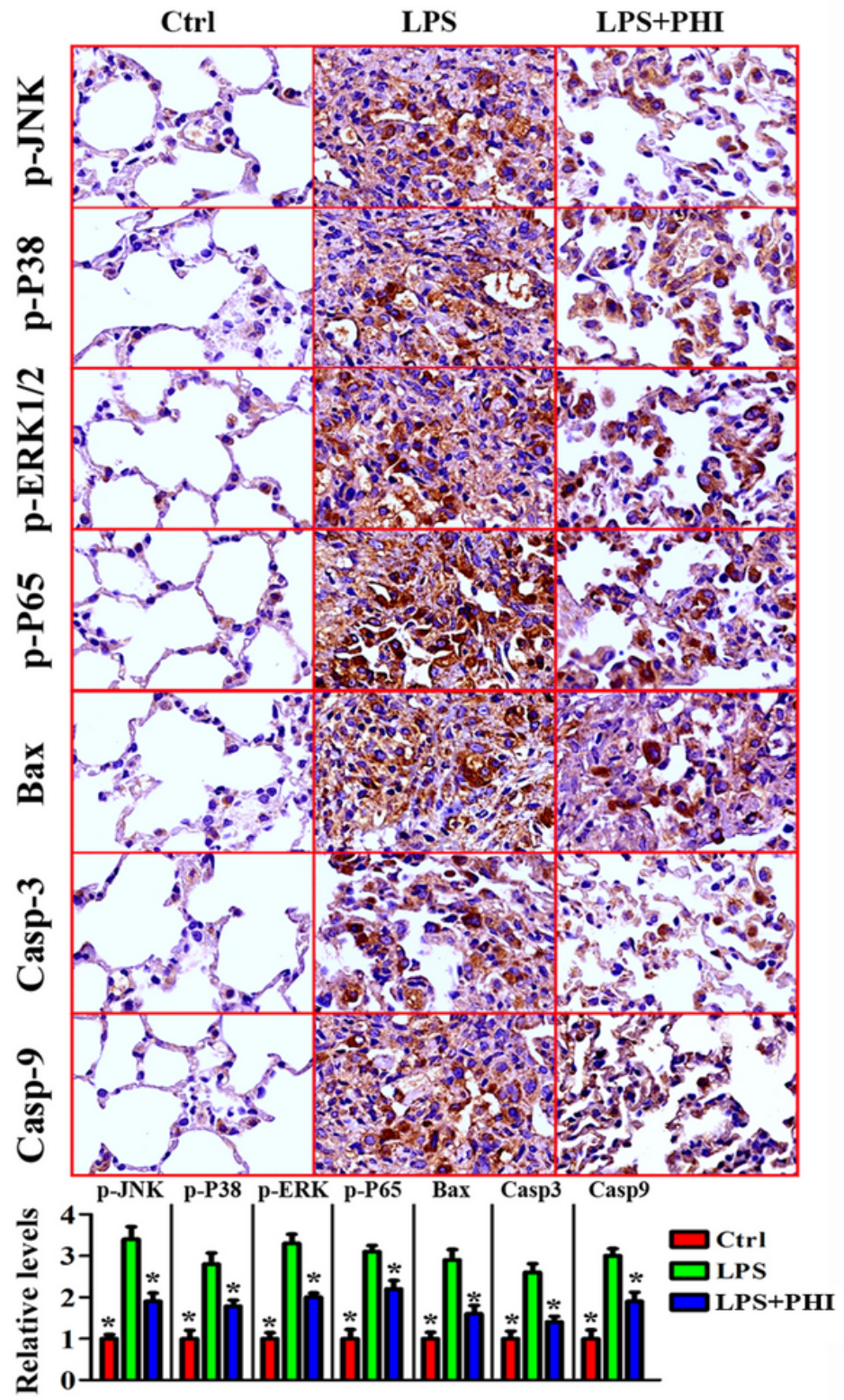

Figure 2

PHI alleviated lipopolysaccharide (LPS)-induced acute pneumonia in vivo. Sprague Dawley rats were stimulated with LPS in the presence or absence of PHI. The rat lung tissues were subjected to hematoxylin and eosin (H\&E) staining and terminal deoxynucleotidyl transferase dUTP nick end labeling (TUNEL) staining (a). The protein expression levels of tumor necrosis factor (TNF)-a signal pathwayrelated proteins were detected by western blotting (b) and immunohistochemistry (c). The results are presented as bars (left) and curves (right). Bar $=100 \mu \mathrm{m}$. Data are expressed as mean \pm standard deviation. $n=10 .{ }^{*}<0.05$. 
Figure 3
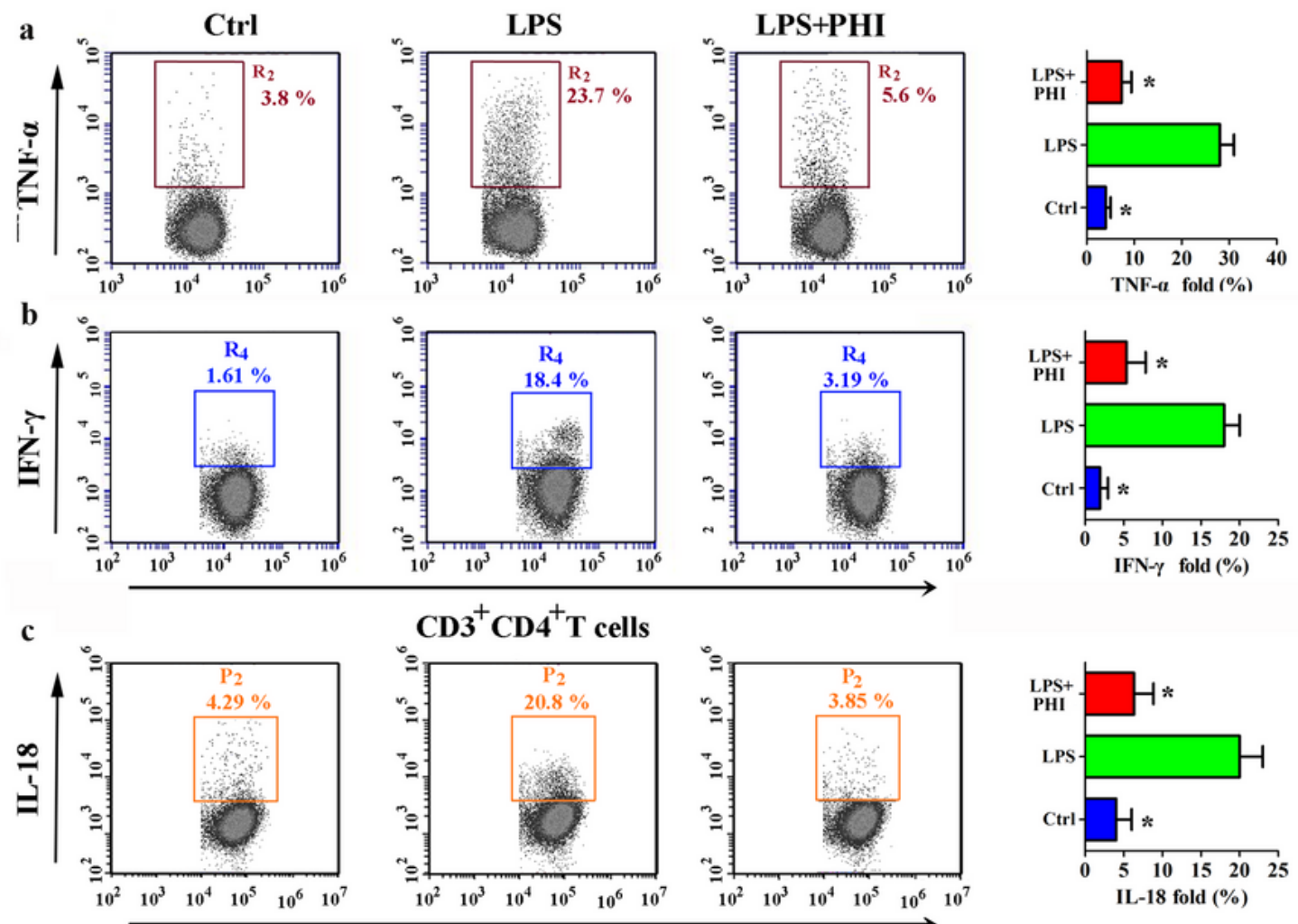

$\mathrm{CD3}^{+} \mathrm{CD}^{+} \mathrm{T}$ cells
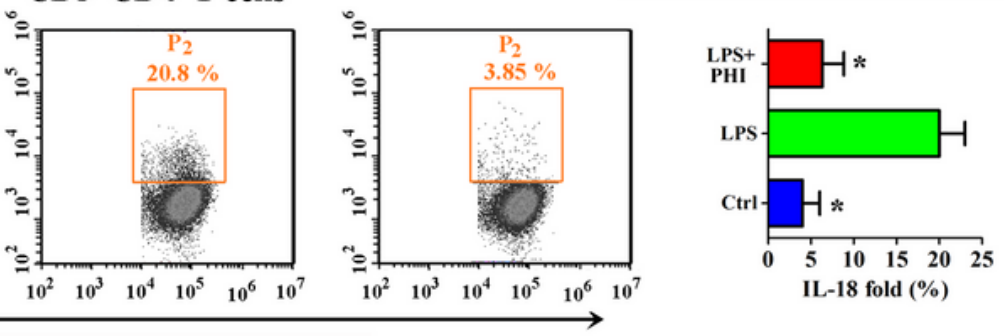

d

$\mathrm{CD68}^{+}$Macrophage

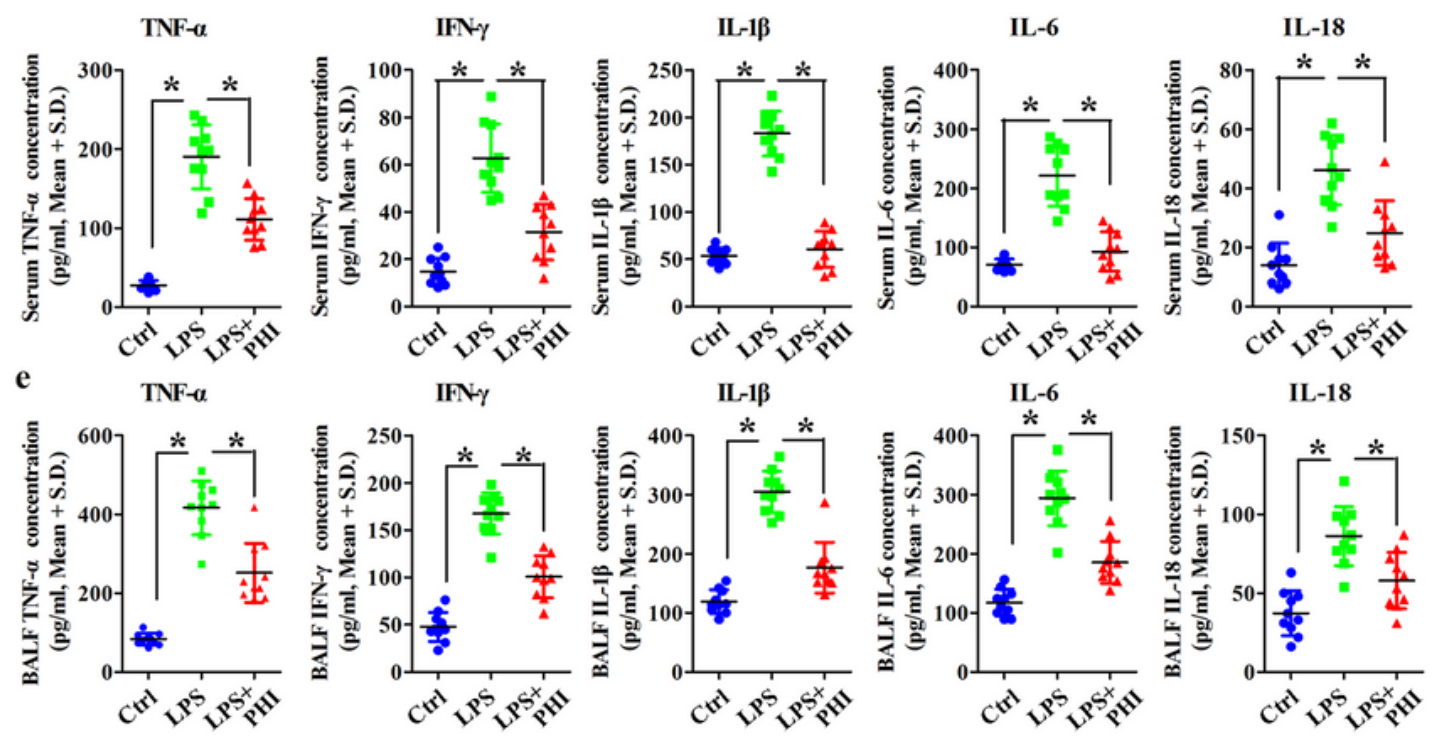

\section{Figure 3}

$\mathrm{PHI}$ alleviated lipopolysaccharide (LPS)-induced acute inflammation in vivo. The levels of tumor necrosis factor (TNF)-a (a), interferon (IFN)-y (b), and interleukin (IL)-18 (c) in the bronchoalveolar fluid (BALF) of rats were detected by flow cytometry. The levels of TNF-a, IFN- - , IL-1 $1 \beta$, IL-6, and IL-18 in the serum (d) and BALF (e) were detected by enzyme-linked immunosorbent assay (ELISA). Experiments were performed in triplicates. Data are expressed as mean \pm standard deviation. ${ }^{*} \mathrm{P}<0.05$. 
Figure 4
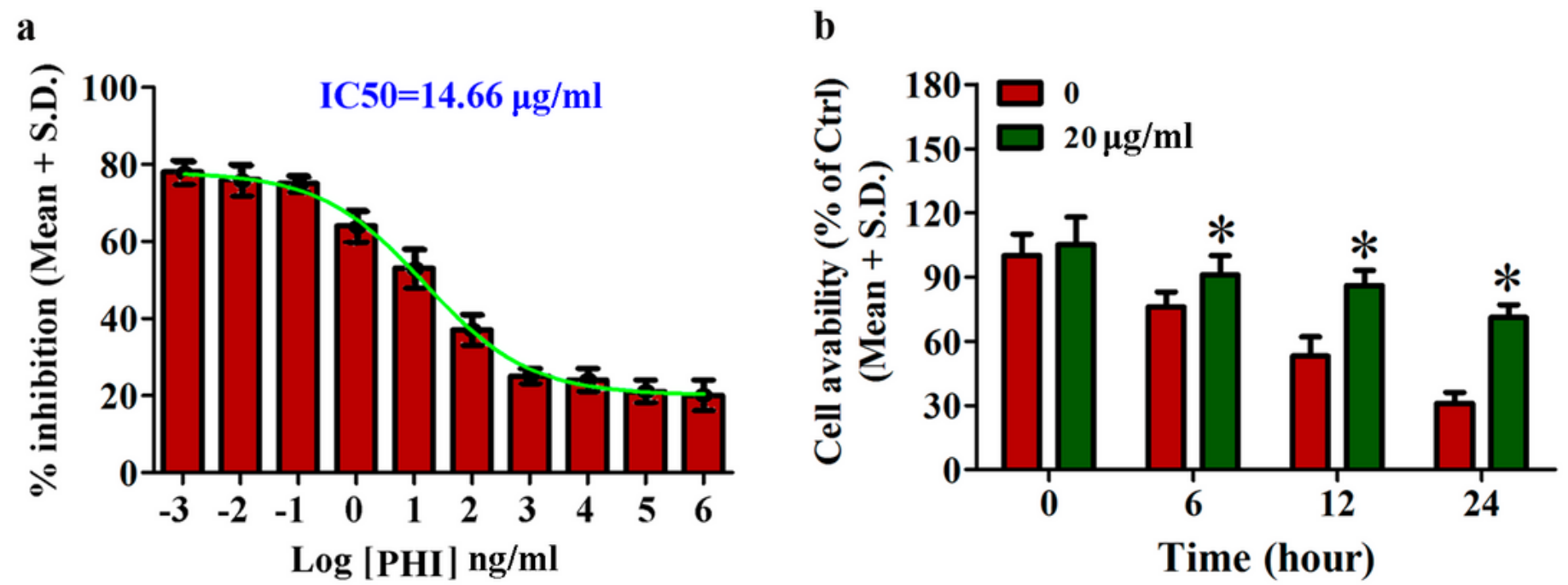

c
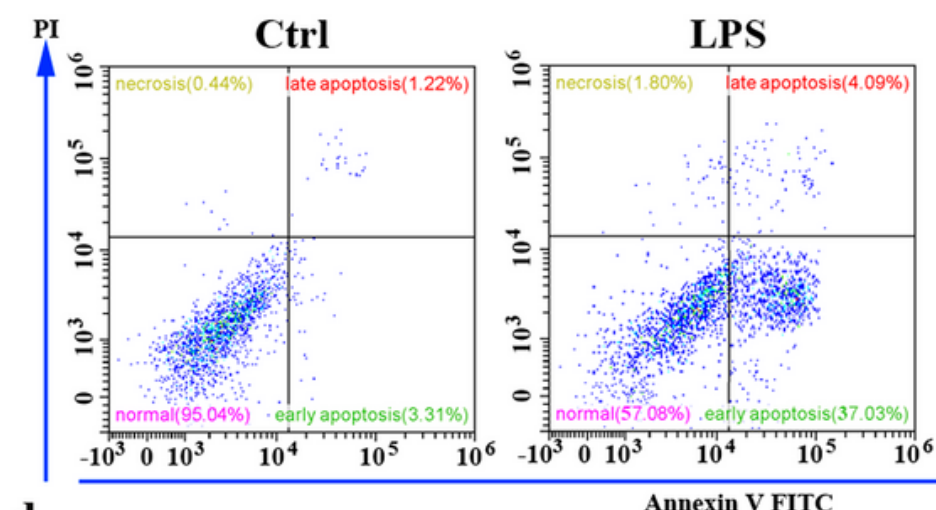

\section{LPS+PHI-20 $\mu \mathrm{g} / \mathrm{ml}$}
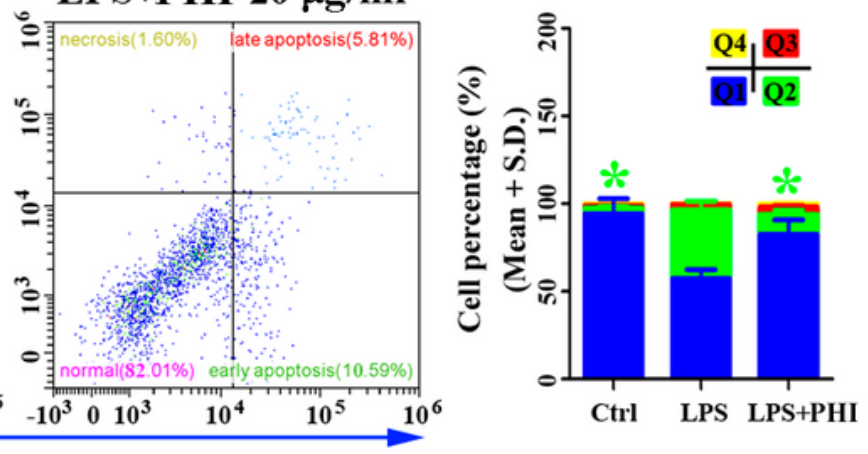

d

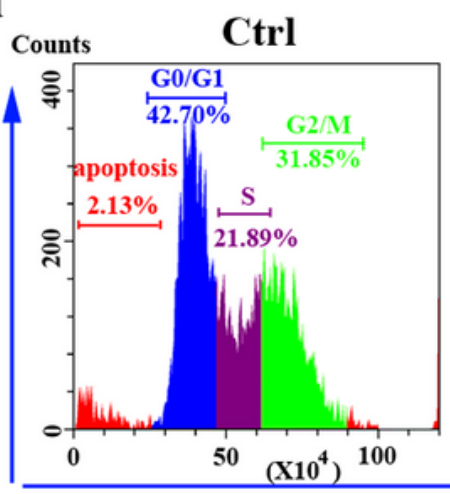

LPS

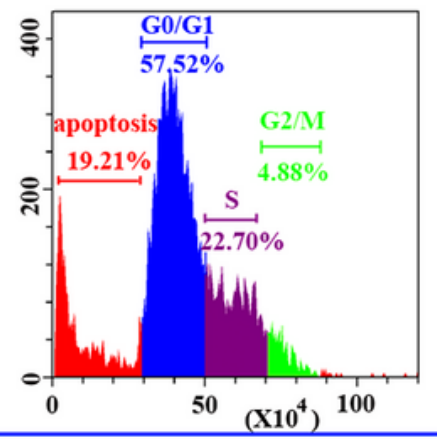

LPS+PHI-20 $\mu \mathrm{g} / \mathrm{ml}$
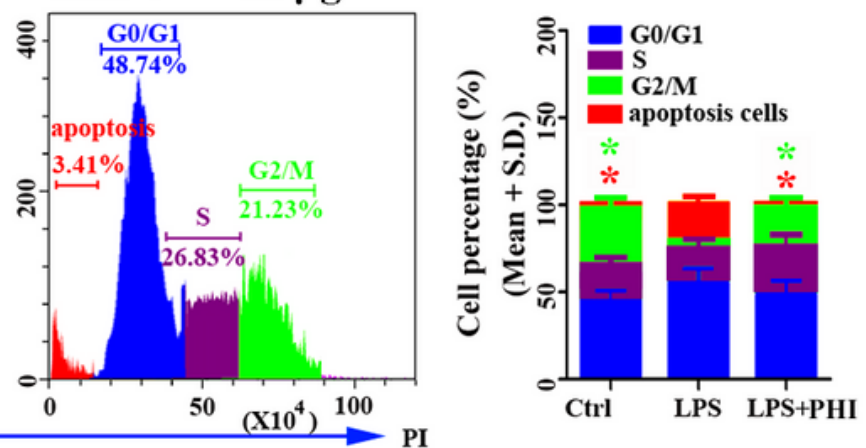

Figure 4

PHI mitigated lipopolysaccharide (LPS)-induced cell apoptosis by modulating the tumor necrosis factor (TNF)-a signaling pathway in vitro. (a) The A549 cells were pre-stimulated with LPS ( $1 \mu \mathrm{g} / \mathrm{mL})$ for $2 \mathrm{~h}$. Next, the A549 cells were treated with various concentrations of PHI (10-3 to $106 \mu \mathrm{g} / \mathrm{ml}$; based on phillygenin concentration) for $24 \mathrm{~h}$. The cell proliferation rates were analyzed. (b) The viability of A549 cells incubated with $20 \mathrm{nM}$ PHI for 6,12 , and $24 \mathrm{~h}$. The effect of $20 \mu \mathrm{g} / \mathrm{ml} \mathrm{PHI}$ treatment for $24 \mathrm{~h}$ on cell 
apoptosis (c) and cell cycle (d) was determined by flow cytometry. Experiments were performed in triplicates for each group. Data are expressed as mean \pm standard deviation. ${ }^{*} P<0.05$.

\section{Figure 5}

a
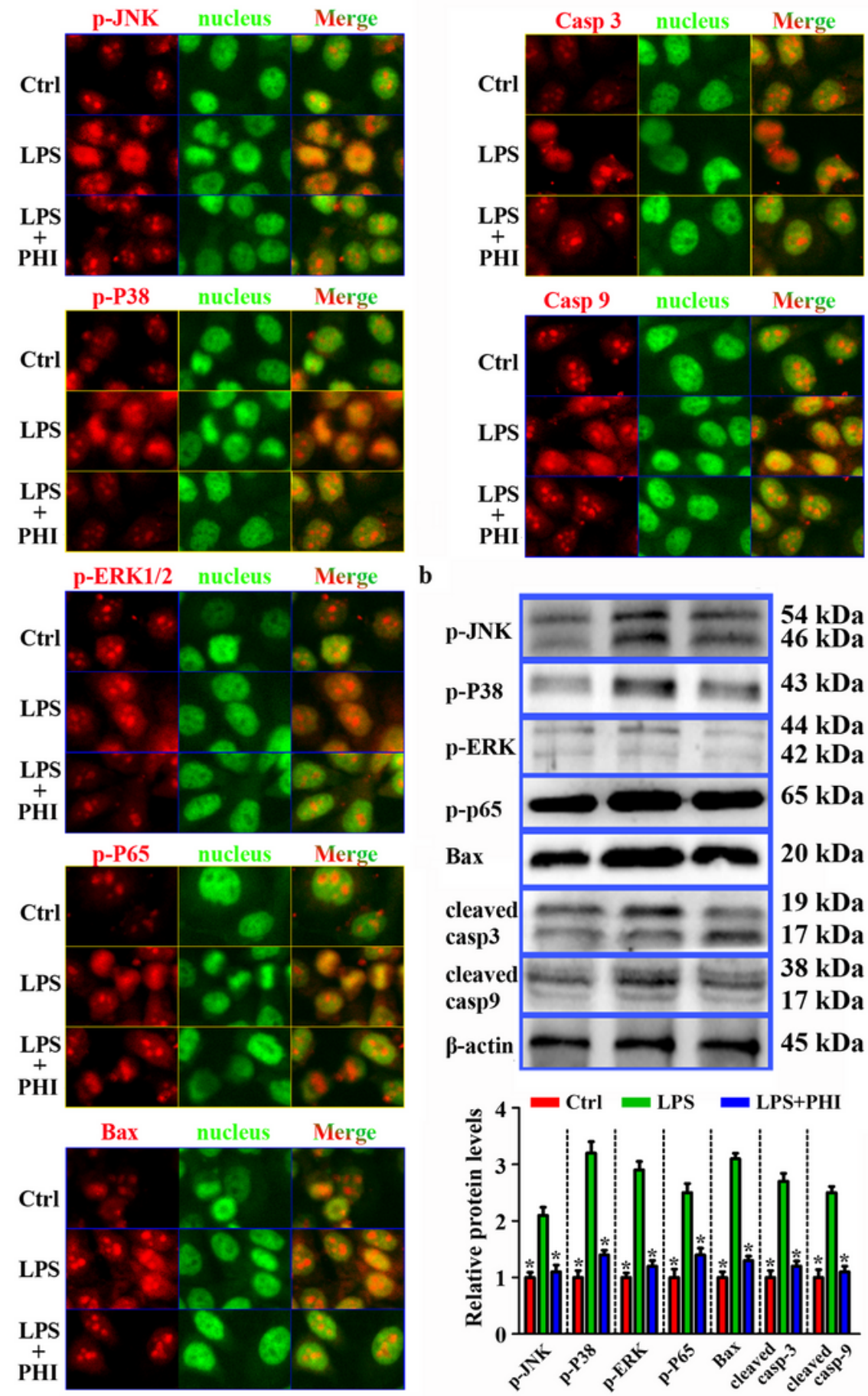

\section{Figure 5}

PHI modulates the tumor necrosis factor (TNF)-a signaling pathway in vitro. The A549 cells were stimulated with lipopolysaccharide (LPS) in the presence or absence of PHI $(20 \mu \mathrm{g} / \mathrm{ml})$. The protein expression levels of p-JNK, p-P38, p-ERK1/2, p-P65, Bax, Bcl-2, caspase-3, and caspase-9 were detected 
by immunofluorescence (a) and western blotting (b). Bar=20 $\mu \mathrm{m}$. Data are expressed as mean \pm standard deviation. ${ }^{*} \mathrm{P}<0.05$

\section{Supplementary Files}

This is a list of supplementary files associated with this preprint. Click to download.

- Supplementarylnfamation.docx 